\title{
Anatomical study of the renal excretory system in pigs. A review of its characteristics as compared to its human counterpart
}

\author{
F.A. Gómez*, L.E. Ballesteros*, H.Y. Estupiñán* \\ Universidad Industrial de Santander, Bucaramanga, Colombia \\ [Received 6 July 2016; Accepted: 24 August 2016]
}

Background: Despite the importance of the pyelocalyceal system in the pig as an experimental model, there is little information about this particular anatomical subject. We determined the morphological characteristics of the renal excretory system in pigs.

Materials and methods: This descriptive cross-sectional study evaluated 130 pairs of kidneys of pigs destined to slaughter. The pyelocalyceal system was subjected to injection technique - corrosion by infusion of polyester resin (85\% Palatal and $15 \%$ Styrene) and subsequent infusion in potassium hydroxide $(\mathrm{KOH})$ for 10 days. The significance level used was $p<0.05$.

Results: The renal excretory system is characterised by the presence of type $A$ major cranial and caudal calyxes seen in 34.3\% of the kidneys (type $A 1$ in $30 \%$ and type $A 2$ in $4.3 \%$ ). type $B$ calyxes, corresponding to minor calyxes draining directly into the renal pelvis, were present in $65.7 \%$ of the specimens (type B1 $59.2 \%$; type B2 $6.5 \%$ of the cases). The number of minor calyxes in the collector system was $7.9 \pm 2.27$ with statistically significant differences in side $(p=0.0047)$. Conclusions: The morphometric characteristics of the kidneys in this study are slightly smaller than reported in humans. Similarly, the incidence of type A renal excretory system distribution is highest in humans and lowest in pigs. Due to its few morphological differences, the pig kidney is an excellent model for teaching-learning processes, for research purposes, and for training of urologic applications. (Folia Morphol 2017; 76, 2: 262-268)

Key words: minor calyxes, pig, renal pelvis, ureter, kidney

\section{INTRODUCTION}

The evidence gathered about the morphological and functional similarity between the human and the porcine kidney is abundant, resulting in the use of this species for experimental models and for therapeutic and surgical applications. However, consolidated information on some aspects of the pig kidney morphometry, as well as the configuration of its excretory system is still missing $[25,28,29]$.
Mean weights within a range of $98-280 \mathrm{~g}$ and mean lengths of $11.8-13 \mathrm{~cm}$ are reported for pig kidneys, with the left kidney being a little longer than the right kidney $[7,9,12,21,29]$. These dimensions have also been reported in humans with slight differences, as well as those of thickness and width of the cranial and caudal poles [26, 27].

The few works devoted to describing the pig excretory system, aim at presenting patterns of distribution

Address for correspondence: Dr. F.A. Gómez, DMV, MSc, Associate Professor, Universidad Industrial de Santander. Bucaramanga, Colombia, tel: +57 (7) 6426430, Mobile: +57 3002004432, e-mail: falegom@uis.edu.co

*These authors contributed equally to the work. 
and number of minor calyxes, but have not provided the morphometric data of the components of the system $[23,29]$.

Sampaio et al. [29] reported the presence of one type of renal excretion in the pig characterised by the presence of major cranial and caudal calyxes (40\%), and another one where the calyxes from the mid region drain directly into the renal pelvis $(60 \%)$. In the human kidney, the prevalence (62\%) of an excretory system formed by major superior and inferior calyxes [28] has been reported.

The number of minor calyxes in the collecting system of the pig varies between 4 and 19, with the cranial polar region having a higher number than the caudal polar region. Similarly, it has been reported that the morphology of the structures the pyelocalyceal system is bilaterally symmetrical or mirror image in $56 \%$ of the cases [29]. These anatomical features are quite close to those reported in human specimens $[25,26,28]$.

The importance of characterising the excretory system in pigs resides in the use of this species for teaching-learning processes in compared anatomy, and as an experimental model for surgical procedures of the kidney and renal physiology $[4,5,8,10,13,14$, $16,19,23,33]$. This work intends to generate meaningful information on these renal structures through the evaluation of a sample of commercial pigs within the context of comparative anatomy between human and porcine kidneys.

\section{MATERIALS AND METHODS}

This descriptive cross-sectional study assessed the characteristics of the excretory system of 130 pairs of kidneys of commercial breeds of pigs (Pietrain, Landrace Belga and Large White mixed breeds) with a mean weight of $85-90 \mathrm{~kg}$ and a mean age of 5 months destined for slaughter, obtained from Frigorífico Vijagual of Bucaramanga, Colombia. The organs were subjected to an exsanguination process for $6 \mathrm{~h}$ in a water source.

A reference suture in surgical silk was placed at the distal segment of each ureter and $7 \mathrm{~mL}$ of semisynthetic polyester resin (85\% Palatal GP40L; $15 \%$ Styrene) dyed with mineral yellow were infused through a No. 14 catheter. The specimens were left in water for $24 \mathrm{~h}$ and were subsequently subjected to a corrosion process in a $15 \%$ potassium hydroxide $(\mathrm{KOH})$ solution for 10 days [28]. The morphological characteristics of the pig excretory system were typified as A and B. Type A presents with major cranial and caudal calyxes, which in turn receive drainage from minor calyxes from the ventral and dorsal portions of the kidney. The infundibula of the major cranial and caudal calyxes can be either long and narrow, or short and wide (type A1 and A2). Type B presents with calyxes draining directly into the renal pelvis independently of cranial and caudal calyxes. This type has two expressions: type B-1, where in the mid renal area is drained by a group of major calyxes, independent from the cranial and caudal calyxes, ending in the renal pelvis; and type B-2, characterised by minor calyxes draining the mid region and ending directly in the renal pelvis $[25,29]$.

The number of minor calyxes draining the cranial, mid and caudal regions was also determined, along with the symmetrical nature of the types of excretory system distribution. In addition, the patterns of the renal pelvis were observed, these being either intermediate or branched with major calyxes with long and narrow infundibula, ampullar with calyxes with short infundibula draining directly into a wide renal pelvis, and bifurcated with very long calyxes converging at the pyeloureteral junction [3]. External measurements of the kidneys and the pyelocalyceal structures were taken with a digital calibrator (Mitutoyo ${ }^{\circledR}$ ). A digital camera was used to take photographic records of each of the specimens evaluated.

\section{Statistical analysis}

The continuous variables were analysed using Student's $\mathrm{t}$ test, whereas the discrete variables were assessed using Pearson's $\chi^{2}$ test. The results were evaluated using the "Epi-Info 3.5.4" statistical programme. The significance level used for this research was $p<0.05$.

\section{RESULTS}

One hundred and thirty pairs of pig kidneys were assessed, with a mean length of $120 \pm 9.22 \mathrm{~mm}$ and a mean thickness of $27.9 \pm 4.48 \mathrm{~mm}$ (Table 1).

The calibre of the ureter was $7.16 \pm 1.84 \mathrm{~mm}$ for the right kidney and $7.11 \pm 1.71 \mathrm{~mm}$ for the left kidney. The excretory system to both kidneys was characterised taking into account the width and height of the renal pelvis, and the calibre and length of the cranial and caudal infundibula (Table 2).

Type A calyx distribution pattern was observed in $49(37.7 \%)$ specimens of the right kidney, 42 (32.3\%) 
Table 1. External morphometric measurements of 130 pairs of porcine kidneys

\begin{tabular}{lccccc}
\hline & $\begin{array}{c}\text { Kidney length } \\
{[\mathrm{mm} \pm \text { SD] }}\end{array}$ & $\begin{array}{c}\text { Cranial pole width } \\
{[\mathrm{mm} \pm \text { SD] }}\end{array}$ & $\begin{array}{c}\text { Hilus width } \\
{[\mathrm{mm} \pm \text { SD] }}\end{array}$ & $\begin{array}{c}\text { Caudal Polo width } \\
{[\mathrm{mm} \pm \text { SD] }}\end{array}$ & $\begin{array}{c}\text { Thickness } \\
{[\mathrm{mm} \pm \text { SD] }}\end{array}$ \\
\hline Right kidney & $119.9 \pm 9.48$ & $56.6 \pm 6.26$ & $52.4 \pm 5.59$ & $52.6 \pm 6.93$ & $28 \pm 4.25$ \\
Left kidney & $121.5 \pm 8.96$ & $57.2 \pm 7.2$ & $52.8 \pm 6.64$ & $52.1 \pm 6.53$ & $27.82 \pm 4.7$ \\
Total & $120 \pm 9.22$ & $56.9 \pm 6.73$ & $52.6 \pm 6.12$ & $52.4 \pm 6.73$ & $27.9 \pm 4.48$ \\
\hline
\end{tabular}

SD - standard deviation

Table 2. Pig renal excretory system characterisation

\begin{tabular}{lcccccc}
\hline & $\begin{array}{c}\text { Pelvis width } \\
{[\mathbf{m m} \pm \text { SD] }}\end{array}$ & $\begin{array}{c}\text { Pelvis height } \\
{[\mathbf{m m} \pm \text { SD] }}\end{array}$ & $\begin{array}{c}\text { Cranial infundibula } \\
\text { calibre } \\
{[\mathbf{m m} \pm \text { SD] }}\end{array}$ & $\begin{array}{c}\text { Cranial infundibula } \\
\text { length } \\
{[\mathbf{m m} \pm \text { SD] }}\end{array}$ & $\begin{array}{c}\text { Caudal infundibula } \\
\text { calibre } \\
{[\mathbf{m m} \pm \text { SD] }}\end{array}$ & $\begin{array}{c}\text { Caudal infundibula } \\
\text { length } \\
{[\mathbf{m m} \pm \text { SD] }}\end{array}$ \\
\hline Right kidney & $13.14 \pm 4.05$ & $11.55 \pm 4.46$ & $7.86 \pm 2.3$ & $20.91 \pm 5.81$ & $7.44 \pm 2.29$ & $16.88 \pm 5.45$ \\
Left kidney & $13.48 \pm 4.06$ & $11.82 \pm 4.21$ & $7.97 \pm 2.38$ & $20.94 \pm 5.66$ & $7.41 \pm 2.34$ & $17.78 \pm 6.02$ \\
\hline
\end{tabular}

SD — standard deviation

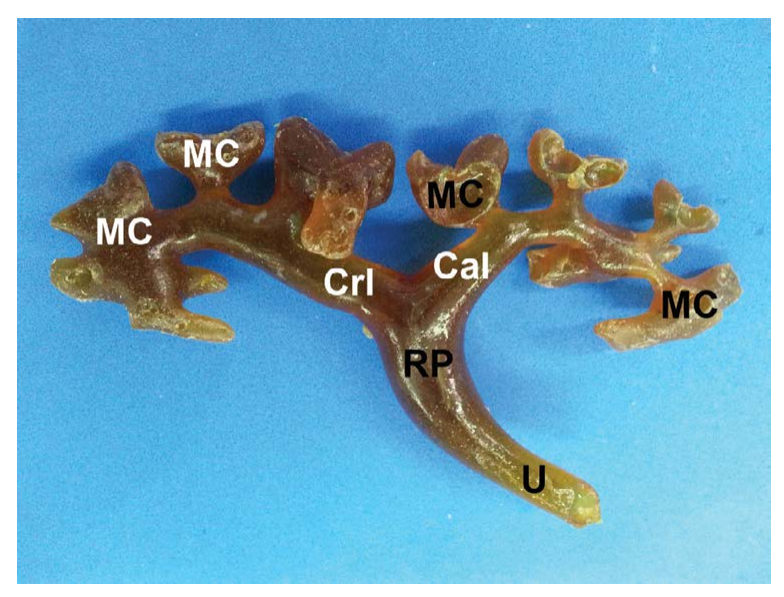

Figure 1. Type A1 distribution pattern. Branched renal pelvis; $\mathrm{U}$ - ureter; $\mathrm{RP}$ - renal pelvis; $\mathrm{MC}$ - minor calyx; $\mathrm{Crl}$ — cranial infundibulum; $\mathrm{Cal}$ — caudal infundibulum.

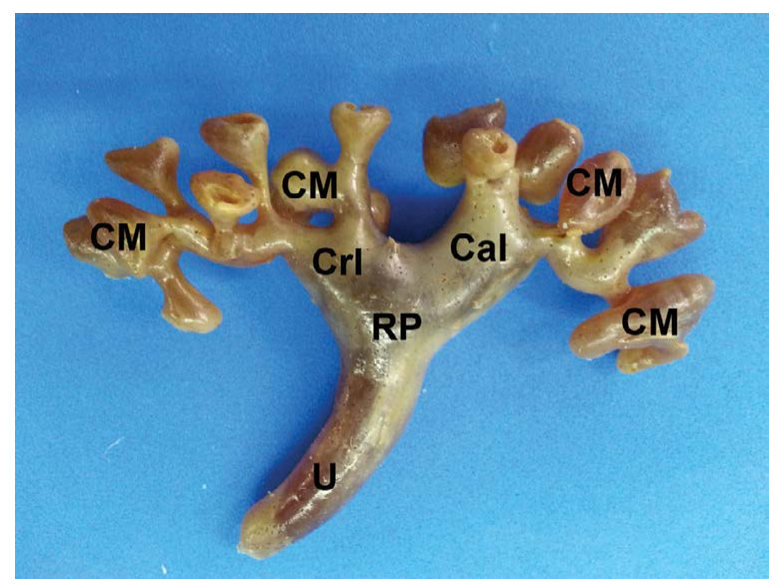

Figure 2. Type $A 2$ distribution pattern. Branched renal pelvis; $\mathrm{U}$ - ureter; $\mathrm{RP}$ - renal pelvis; $\mathrm{CM}$ - minor calyx; $\mathrm{Crl}$ — cranial infundibulum; Cal — caudal infundibulum. of which were type $A 1$ (Fig. 1) and 7 (5.4\%) - type A2 (Fig. 2). Type B was observed in 81 (62.3\%) cases, $73(56.1 \%)$ corresponding to type B1 (Fig. 3) and $8(6.2 \%)$ specimens to type B2 (Fig. 4). Type A calyx distribution pattern was observed in 40 (30.8\%) left kidneys, 36 (27.7\%) of which were type $A 1$ and 4 (3.1\%) - type A2. Type B was found in 90 (69.2\%) cases, 81 (62.3\%) of which were type B1 and 9 (6.9\%) were type B2. There were no statistically significant differences with respect to the side of occurrence ( $p=0.239)$.

The number of minor calyxes in the excretory system was within a range of 4-15 calyxes (mean $7.9 \pm 2.27$ ). The number of calyxes in the right collector system was $7.75 \pm 2.29$ and $8.02 \pm 2.26$ in the left collector system with significant differences with respect to the side of occurrence $(p=0.0047)$. We determined the number of calyxes in the cranial, mid and caudal regions (Fig. 5; Table 3).

The morphologic expression of the structures of the pyelocalyceal system was symmetric in 66 (50.8\%) cases and asymmetric in 64 (49.2\%) specimens. On average, $4.5 \pm 1.62$ minor calyxes drained into the major cranial calyxes in a type $A$ distribution pattern, whereas $2.7 \pm 1.23$ minor calyxes drained into the major caudal calyx in type $B$ distribution pattern (Table 4).

A branched renal pelvis was observed in 182 (70\%) anatomical specimens, followed by the bifurcated form with $58(22.3 \%)$ specimens, whereas the ampullar pelvis was present in 20 (7.7\%) specimens, with this difference being statistically significant 


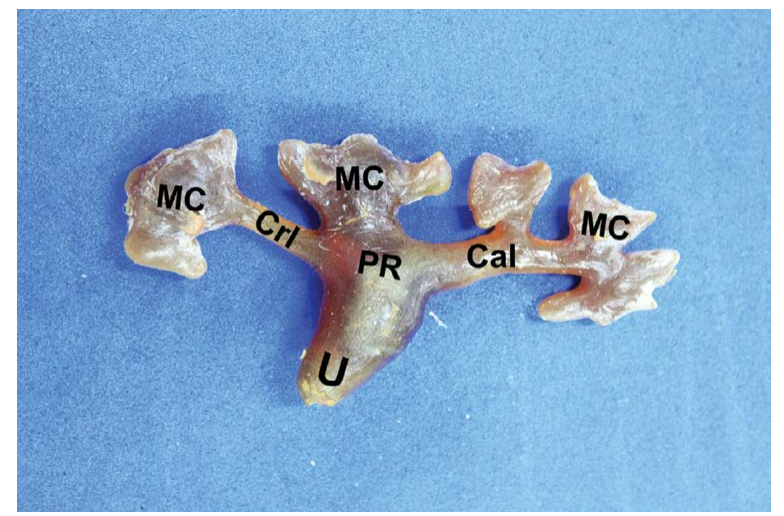

Figure 3. Type B1 distribution pattern. Branched renal pelvis; $\mathrm{U}$ - ureter; PR — renal pelvis; $\mathrm{MC}$ - minor calyx; $\mathrm{Crl}$ - cranial infundibulum; Cal — caudal infundibulum.

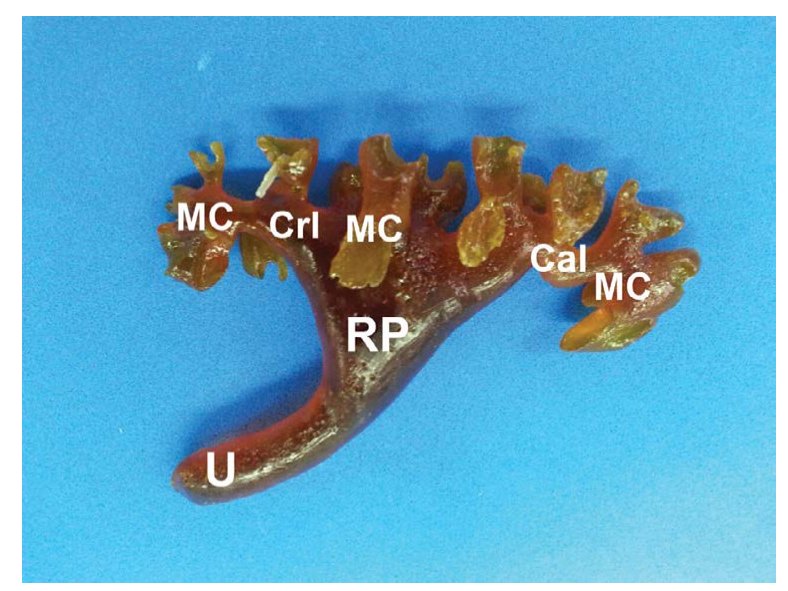

Figure 4. Type B2 distribution pattern. Ampullary renal pelvis; $\mathrm{U}$ - ureter; $\mathrm{RP}$ - renal pelvis; $\mathrm{MC}$ - minor calyx; $\mathrm{Crl}$ — cranial infundibulum; Cal — caudal infundibulum.

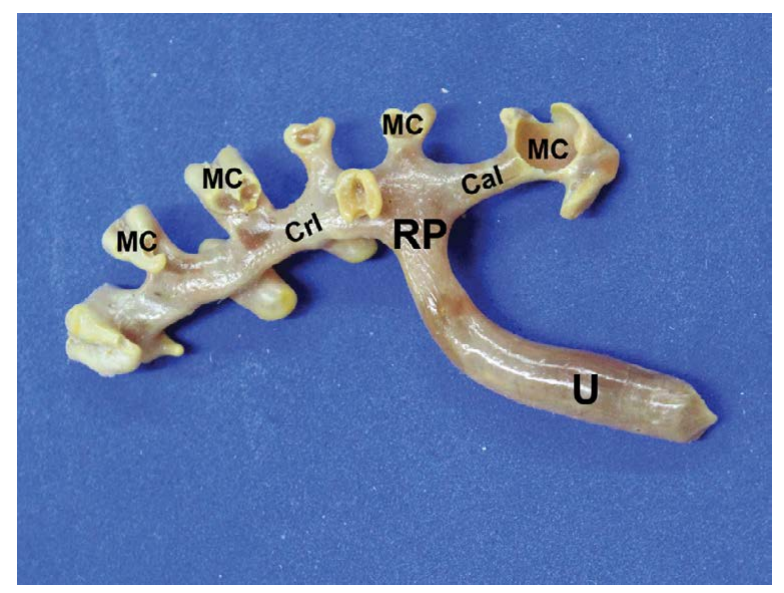

Figure 5. Minor calyces distributed in cranial, middle and caudal regions. Branched renal pelvis; $\mathrm{U}$ - ureter; $\mathrm{RP}$ - renal pelvis; $\mathrm{MC}$ - minor calyx; $\mathrm{Crl}$ — cranial infundibulum; Cal — caudal infundibulum.
Table 3. Number of minor calices in the pig renal excretory system

\begin{tabular}{lccc}
\hline & Cranial pole & Mid zone & Caudal pole \\
\hline Right kidney & $3.61 \pm 1.57$ & $1.63 \pm 0.83$ & $3.07 \pm 1.39$ \\
Left kidney & $3.99 \pm 1.58$ & $1.61 \pm 0.88$ & $3 \pm 1.52$ \\
\hline
\end{tabular}

$(p=0.00001)$. Concerning the elements of the renal pedicle, the structures of the pyelocalyceal system presented a posterior topographic location in all cases. No bifid ureters were observed.

\section{DISCUSSION}

The pig has replaced the rabbit or the dog as an experimental model for diverse urological or haemodynamic procedures and for surgical training, due to the similarity of the kidney in both humans and pigs $[11,20,29,30]$. The morphometry of the porcine excretory system has been scarcely described [34].

The dimensions of length, width at the hilum, and thickness of the kidney in young adult pigs reported in previous studies [31,32] are similar to the findings of the present work. However, these general descriptions do not point to morphometric differences between cranial and caudal poles that represent the concentration of renal functional units with their respective excretory structures. In agreement with the findings of Sampaio et al. [29], in the present study the cranial pole was $56.9 \mathrm{~mm}$ wide, being larger than the caudal pole. In humans, a mean length of $11.8 \mathrm{~cm}$, $6.44 \mathrm{~cm}$ for the cranial pole, $5.49 \mathrm{~cm}$ for the caudal pole and a thickness of $3.29 \mathrm{~cm}$ have been reported, with these measures being slightly larger than those reported in pigs. Therefore, the morphometry of the porcine kidney can be considered as similar to that of the human kidney, an aspect of great relevance in selecting this animal species for experimental studies where the renal size is an important aspect $[26,27]$.

With regard to calyceal structures, our findings are similar to a previous report of the porcine pyelocalyceal system [29], which indicates type B as the most frequent $(60 \%)$ pattern, followed by type $A$ with $40 \%$. We disagree with that job in the incidence of type B1, reported in the present study with a higher incidence than type B2, whereas Sampaio et al. [29] reported type $B 2$ as the most common, in $54 \%$ of the cases. In contrast with pigs, the pattern characterised by the presence of superior and inferior major calyxes (type A) is reported with an incidence of $62 \%$ in humans, 
Table 4. Number of minor calices by type

\begin{tabular}{|c|c|c|c|c|c|c|c|}
\hline & \multicolumn{3}{|c|}{ Type A (n = 44) } & \multicolumn{4}{|c|}{ Type B (n = 86) } \\
\hline & Cranial pole & Caudal pole & Total by type & Cranial pole & Mid zone & Caudal pole & Total by type \\
\hline Mean & 4.5 & 3.6 & 4.05 & 3.4 & 1.63 & 2.7 & 2.58 \\
\hline Standard deviation & 1.62 & 1.60 & 1.66 & 1.43 & 0.83 & 1.23 & 1.40 \\
\hline
\end{tabular}

Table 5. Morphometry of the collecting system in adult pigs

\begin{tabular}{lcccccc}
\hline & $\begin{array}{c}\text { Pelvis width } \\
{[\mathrm{mm} \pm \text { SD] }}\end{array}$ & $\begin{array}{c}\text { Pelvis height } \\
{[\mathrm{mm} \pm \mathrm{SD}]}\end{array}$ & $\begin{array}{c}\text { Cranial infun- } \\
\text { dibula length } \\
{[\mathrm{mm} \pm \text { SD] }}\end{array}$ & $\begin{array}{c}\text { Cranial infun- } \\
\text { dibula calibre } \\
{[\mathrm{mm} \pm \text { SD] }}\end{array}$ & $\begin{array}{c}\text { Caudal infun- } \\
\text { dibula length } \\
{[\mathrm{mm} \pm \text { SD] }}\end{array}$ & $\begin{array}{c}\text { Caudal infun- } \\
\text { dibula calibre } \\
\text { [mm } \pm \text { SD] }\end{array}$ \\
\hline Szymański et al. [34] & $14.1 \pm 5.5$ & $13.7 \pm 5.4$ & $18 \pm 7.3$ & $6.6 \pm 2.5$ & $16.3 \pm 6.2$ & $8 \pm 2.9$ \\
This study & $13.3 \pm 4.05$ & $11.7 \pm 4.33$ & $20.9 \pm 5.73$ & $7.4 \pm 2.34$ & $18.6 \pm 5.73$ & $7.4 \pm 2.31$ \\
\hline
\end{tabular}

SD — standard deviation

whereas type B is reported with an incidence of 38\%. This shows that while in the majority of human kidneys an intercalyceal space can be observed, in pigs this area is occupied by the drainage of the calyxes of the mid region [28, 29].

The number of minor calyxes observed per kidney in the present study (7.9) is similar to what has been reported previously in both pigs and humans. Similarly, our findings are consistent with regard to the higher occurrence of minor calyxes draining into the calyx of the cranial pole (3.8-4.2), followed those draining into the caudal pole (3-3.2) and to a lesser extent (1.6) those draining into the mid region [24, 27-29, 34]. The morphometric findings of the pyelocalyceal system of the present work present slight differences with those reported by Szymański et al. [34] in a sample of adult pigs weighing 70-110 kg (Table 5). These differences could be explained by the size of the anatomical specimens, the methodology utilised, and the size of the pigs examined. We observed the symmetric expression of excretory systems types A and B in a percentage (50.8\%) slightly lower than that reported by Sampaio et al. [29]; in humans, this feature has been reported within a range of $47-40 \%[26,28]$.

Consistent with the findings of numerous authors $[3,6,17,22,24,34,35]$ in our series we found the ampullar type of renal pelvis as having the lowest incidence (5.6-10\%). Of note, Szymański et al. [34] reported this pattern with a significant frequency of $30 \%$, while presenting disagreement about the most frequent type. Consistent with our investigation, some works $[22,34]$ have reported the intermedi- ate or branched type as the most common occurrence, with an incidence of $47.2-70 \%$. Others [3, 6, $24]$ indicate the bifurcated presentation as the most common one, within a range of $45-60 \%$. Since early hydronephrosis expresses itself morphologically with the presence of an ampullar pelvis in humans, it has been postulated that before labelling this feature as an anatomical variant in the clinical scenario, one must rule out an urinary tract obstruction generated by lithiasis, stenosis of the pyeloureteral junction, vesicoureteral reflux, or extrinsic compression caused by light adhesions of the lower polar renal arteries or the gonadal vessels $[6,35]$. Similarly, it has been postulated that since bifurcated renal pelvises handle smaller urinary volumes, they could become an anatomical substrate for the formation of stones inside these structures $[1,18]$.

Treatment of small renal tumours has evolved from radical nephrectomy to cryoablation and radiofrequency ablation of the masses detected. Other non-invasive tumour ablation techniques such as focused high-density ultrasound are still at an experimental stage. The main complications of cryoablation and radiofrequency ablation relate to injuries of the structures located in the renal sinuses, mainly in the pyelocalyceal system. The use of these technologies in the porcine model has resulted in urinary extravasation, fistulas and the occurrence of abscesses secondary to the accidental puncture of the renal pelvis or calyxes. Due to the similarity of the excretory system, skills acquired through training with the pig model are desirable to minimise these complications when the above therapeutic applications, as well as several 
surgical applications (e.g., sutures of the pyelocalyceal system, catheterisation, and kidney transplant) are used in humans $[2,15,33]$.

\section{CONCLUSIONS}

Distribution patterns of the types A and B in the porcine excretory system are inversely proportional in occurrence to what has been reported in humans. The number of minor calyxes found in pigs is very similar to what is observed in the human kidney. The findings of the present study enrich the information about the morphometry of the excretory system of the pig. An adequate knowledge of the morphometric aspects and the characterisation of the renal pelvis facilitate the performance of non-invasive surgical procedures, with the resulting prevention of iatrogenic injuries. Thus, the pig model allows for excellent training for the skills required for the manipulation of the pyelocalyceal system.

\section{Acknowledgements}

To Frigorífico Vijagual in the City of Bucaramanga, Colombia, for the donation of specimens for this research.

To undergraduate students Fausto Arenas, Josimar Sneider Rincon and Juan Camilo Alvarez for their involvement in the preparation of the anatomical specimens.

\section{REFERENCES}

1. Acar C, Küpeli B, Gürocak S, et al. Is pelvicaliceal anatomy a risk factor for stone formation in patients with solitary upper caliceal stone? Urology. 2006; 67(6): 1159-1163, doi: 10.1016/j.urology.2005.12.025, indexed in Pubmed: 16750255.

2. Aron M, Gill IS. Renal tumor ablation. Curr Opin Urol. 2005; 15(5): 298-305, indexed in Pubmed: 16093852.

3. Augustyn M. Variation of the calicopelvic system of the human kidney in ontogenetic development. Folia Morphol. 1978; 37(2): 157-165, indexed in Pubmed: 308905.

4. Bagetti Filho HJS, Pereira-Sampaio MA, Favorito LA, et al. Pig kidney: anatomical relationships between the renal venous arrangement and the kidney collecting system. J Urol. 2008; 179(4): 1627-1630, doi: 10.1016/j. juro.2007.11.040, indexed in Pubmed: 18295250.

5. Brashears JH, Raj GV, Crisci A, et al. Renal cryoablation and radio frequency ablation: an evaluation of worst case scenarios in a porcine model. J Urol. 2005; 173(6): 2160-2165, doi: 10.1097/01.ju.0000158125.80981.f1, indexed in Pubmed: 15879879.

6. Cavalcanti J, de Carvalho RM, Revoredo W. Morphological study of the pyelo-calyce-pyramidal system in human kidney. Rev Chil Anat. 1996; 14(2): 163-168.
7. Chaveau A, Arloing S, Lesbre FX. Traité d' anatomie compare des animaux domestiques. Bailleére et Fils. 1905; 2: 82.

8. Collyer W, Venkatesh R, Vanlangendonck R, et al. Enhanced renal cryoablation with hilar clamping and intrarenal cooling in a porcine model. Urology. 2004; 63(6): 1209-1212, doi: 10.1016/j.urology.2004.02.008, indexed in Pubmed: 15183991.

9. Dyce KM, Sack WO, Wensing CJ. Textbook ok veterinary anatomy. WB Saunders 1987: 524.

10. Earp PP. Percutaneous renal surgery: new model for learning and training. Int Braz J Urol. 2003; 29(2): 151-154, indexed in Pubmed: 15745500.

11. Gardner SM, Wolf JS, Nakada SY, et al. The unintubated ureterotomy endourologically revisited. J Urol. 1996; 156(3): 1160-1163, indexed in Pubmed: 8709338.

12. Getty R. The anatomy of the domestic animals. Fifth edition. WB Saunders. 1975: 1298.

13. Hammond L, Ketchum J, Schwartz BF. A new approach to urology training: a laboratory model for percutaneous nephrolithotomy. J Urol. 2004; 172(5 Pt 1): 1950-1952, indexed in Pubmed: 15540763.

14. Janzen NK, Perry KT, Han KR, et al. The effects of intentional cryoablation and radio frequency ablation of renal tissue involving the collecting system in a porcine model. J Urol. 2005; 173(4): 1368-1374, doi: 10.1097/01. ju.0000147014.69777.06, indexed in Pubmed: 15758807.

15. Johnson DB, Solomon SB, Su LM, et al. Defining the complications of cryoablation and radio frequency ablation of small renal tumors: a multi-institutional review. J Urol. 2004; 172(3): 874-877, doi: 10.1097/01. ju.0000135833.67906.ec, indexed in Pubmed: 15310987.

16. Kaouk JH, Gill IS, Desai MM, et al. Laparoscopic anatrophic nephrolithotomy: feasibility study in a chronic porcine model. J Urol. 2003; 169(2): 691-696, doi: 10.1097/01. ju.0000036471.82870.23, indexed in Pubmed: 12544344.

17. Kosiński H. Variations in shape and position of human renal pelvis. Folia Morphol. 1987; 46(3-4): 207-214, indexed in Pubmed: 3508142.

18. Kupeli B, Tunc L, Acar C, et al. The impact of pelvicaliceal anatomical variation between the stone-bearing and normal contralateral kidney on stone formation in adult patients with lower caliceal stones. Int Braz J Urol. 2006; 32(3): 287-294, indexed in Pubmed: 16813671.

19. Margulis V, Matsumoto ED, Taylor G, et al. Retrograde renal cooling during radio frequency ablation to protect from renal collecting system injury. J Urol. 2005; 174(1): 350-352, doi: 10.1097/01.ju.0000161596.71457.1b, indexed in Pubmed: 15947688.

20. McDougall EM, Clayman RV, Chandhoke PS, et al. Laparoscopic partial nephrectomy in the pig model. J Urol. 1993; 149(6): 1633-1636, indexed in Pubmed: 8501822.

21. Nickel R, Schummer A, Seiferle E. The viscera of the domestic animals. Second edition. Springer-Verlag 1979: 294.

22. Nizankowski C. Suggestion of new classification of the shape of human renal pelvis with consideration of the number of renal papillae. Folia Morphol. 1978; 37(4): 367-380, indexed in Pubmed: 310794.

23. Pereira-Sampaio MA, Henry RW, Favorito LA, et al. Proportional analysis of the pig renal parenchyma and sinus structures. Cells Tissues Organs. 2008; 187(4): 316-321, doi: 10.1159/000113410, indexed in Pubmed: 18196896. 
24. Piasecki Z, Jugowski F, Piotrowski J. Formy miedniczek nerkowych u człowieka w odlewach i radiogramach. Folia Morphol. 1969; 28: 177-187.

25. Sampaio FJB, Mandarim-de-Lacerda CA. Anatomic classification of the kidney collecting system for endourologic procedures. J Endourol. 1988; 2(3): 247-251, doi: 10.1089/end.1988.2.247.

26. Sampaio FJB, Lacerda CAM. Morphométrie du rein: étude appliquée á l'urologie et á l'imagerie. J Urol. 1989; 95: 77.

27. Sampaio FJB. Inferior pole collecting system anatomy: ita probable role in extracorporeal shock wave lithotripsy. J Urol. 1992; 147: 322.

28. Sampaio FJB. Anatomical classification of the pelviocaliceal system: urologic and radiologic implications. In: Renal Anatomy Applied to Urology. Endourology and interventional Radiology, Thieme Medical Publishers, New York 1993: 5.

29. Sampaio FJ, Pereira-Sampaio MA, Favorito LA. The pig kidney as an endourologic model: anatomic contribution. J Endourol. 1998; 12(1): 45-50, doi: 10.1089/ end.1998.12.45, indexed in Pubmed: 9531151.
30. Schwalb D, Eshghi M, Cord J, et al. The minipig as a practical endourologic model. Journal of Endourology. 1989; 3(1): 85-90, doi: 10.1089/end.1989.3.85.

31. Schwarze E, Schröder L. Compendio de anatomía veterinaria: El sistema visceral. Acribia, Vol. 2 1970: 230.

32. Sisson S, Groosman JD, Getty R. Anatomía de los animales domésticos. Salvat 5 edicion tomo II 1995: 1430-1431.

33. Shingleton $W B$, Farabaugh $P$, Hughson $M$, et al. Effects of cryoablation on short-term development of urinary fistulas in the porcine kidney. J Endourol. 2003; 17(1): 37-40, doi: 10.1089/089277903321196779, indexed in Pubmed: 12639360.

34. Szymański J, Konarska S, Polguj M, et al. Pelvi-caliceal collecting system in swine--authors own anatomical classification. Adv Clin Exp Med. 2012; 21(1): 27-33, indexed in Pubmed: 23214296.

35. Zhang L, Liu C, Li F, et al. Diagnosis of 65 cases of ampullary renal pelvis after postnatal follow-up of 1,167 newborn infants with prenatally suspected hydronephrosis. Exp Ther Med. 2015; 9(1): 151-153, doi: 10.3892/etm.2014.2076, indexed in Pubmed: 25452792. 